\title{
Soil nitrogen-hydrolyzing enzyme activity and stoichiometry following a subtropical land use change
}

\author{
Qian Zhang ${ }^{1}$, Dandan Zhang ${ }^{1}$, Junjun $\mathrm{Wu}^{2}$, Jinsheng $\mathrm{Li}^{1}$, Jiao Feng ${ }^{3}$, and Xiaoli Cheng ${ }^{1}$ \\ ${ }^{1}$ Yunnan University \\ ${ }^{2}$ Wuhan Botanical Garden Chinese Academy of Sciences \\ ${ }^{3}$ Huazhong Agricultural University
}

March 12, 2021

\begin{abstract}
Afforestation; Soil ecoenzymatic C: N: P; Specific enzyme activities; Soil C and N contents.
\end{abstract}

\section{Introduction}

Land use change, a key global change phenomenon, greatly affects ecosystem structure and functioning, particularly, alterations in vegetation types and soil properties induced by land-use profoundly alter soil carbon (C), nitrogen (N) dynamics and microbial activities (Fu et al., 2015; Mbuthia et al., 2015; Rilling et al., 2019; Song et al., 2012; Yue et al., 2020). Although the impacts of land use change on soil C and N pools, and microbial community have been well demonstrated (Cheng et al., 2013; Deng et al., 2016; Moscatelli et al., 2018), the effects of land use change on N-hydrolyzing enzyme activity and stoichiometry remain controversial (Allison et al., 2008; He et al., 2020; Zhang et al., 2019b). For instance, some studies reported conversion of cropland to woodland enhanced N-hydrolyzing enzyme activities and C: N enzyme ratio (Cenini et al., 2016; Feng et al., 2018). Other studies showed that land use change had negative or no effect on N-hydrolyzing enzyme activities or soil enzyme stoichiometry (DeForest and Moorhead, 2020; Fichtner et al., 2014). These inconsistent results can be attributed to different land use management practice and microbial nutrient demand (Sinsabaugh et al., 2016; Wang et al., 2012). Thus, more knowledge on soil $\mathrm{N}$-hydrolyzing enzyme activities in response to different types of land use change is crucial for predictions of $\mathrm{N}$ cycling under future global change scenarios.

Soil N-hydrolyzing enzyme including $\beta-1,4-\mathrm{N}$-acetylglucosaminidase (NAG) and leucine aminopeptidase (LAP) can serve as indicators of energy $\mathrm{N}$ demand (Schimel et al., 2017), which catalyze terminal reactions to depolymerize organic substrates for assimilation of N (Sinsabaugh et al., 2009), and are strongly impacted by changes of soil properties under land use change (Acosta-Martinez et al., 2007; He et al., 2020; Sinsabaugh et al., 2008). For example, conversion of cropland to woodland usually tends to increase soil $\mathrm{N}$-hydrolyzing enzyme activities due to increase in soil organic $\mathrm{N}$ content as soil organic matter is the substrate of enzymatic reaction (Raiesi and Beheshti, 2014), whereas cultivation decreases the soil N-hydrolyzing enzyme activities due to $\mathrm{N}$ fertilizations (Zheng et al., 2020a). Meanwhile, some studies reported that temperature was a key factor explaining the variation in soil N-hydrolyzing enzyme activities (Zhou et al., 2020) with a positive (Waring et al., 2014) and negative (Peng and Wang, 2016; Xu et al., 2017) effects on it. While positive relationship between soil N-hydrolyzing enzyme activities and soil moisture was also be found in some studies (He et al., 2020; Xu et al., 2017). Soil N-hydrolyzing enzyme activity was also affected by soil pH and soil moisture (Fu et al., 2017; Pinsonneault et al., 2016). The changes in soil pH were accompanied by changes in vegetation type which induced positive relationship between soil $\mathrm{pH}$ and N-hydrolyzing enzyme 
activities (He et al., 2020). Despite the importance of the above factors in regulating soil N-hydrolyzing enzyme activities, soil N-hydrolyzing enzyme activities driven by multiple controls under use change are not well examined.

Soil extracellular enzyme stoichiometry (EES) reflects the energy and nutrient controls on microbial metabolism, indicating how shifts in substance and energy allocation alter the according nutrient demand (Cui et al., 2018; Guo et al., 2019; Sinsabaugh et al., 2012; Yang et al., 2020). It has been suggested that ecosystem C: N: phosphorus (P) enzyme stoichiometry greatly varies with land-use types (Hartman and Richardson, 2013; Li et al., 2012). Variations in soil enzyme stoichiometry are consistent with the patterns of microbial nutrient availability under land use change (Sinsabaugh et al., 2008, Waring et al., 2014, Xu et al., 2017). It has been reported that afforestation usually decreases soil enzyme C: $\mathrm{N}$ ratio as higher soil C: $\mathrm{N}$ ratio induced $\mathrm{N}$ limitation for microbial (Feng et al., 2018). But a recent study showed that differences in enzyme stoichiometry between vegetation types were weakly related to the microbial nutrient status (He et al., 2020). Additionally, previous studies have found soil enzyme C: P ratio was inversely related to mean annual temperature (MAT) and precipitation (MAP), while the soil enzyme C: N ratio was positively related to MAP at a global scale (Sinsabaugh et al., 2008). While Cui et al. (2018) reported that plant traits were more important than soil physical and chemical properties in determining EES. Thus, evaluating enzyme stoichiometry patterns and their drivers could improve our understanding of N, P limitations in response to land use change.

The Danjiangkou Reservoir area is a water source for the Middle Route of China's South-to-North Water Transfer Project. In order to protect water quality of the reservoir and restore riparian ecosystem function, large areas of afforestation have been conducted to reduce soil erosion, water pollution (Zhu et al., 2010). Our previous studies reported that afforestation greatly impacted soil $\mathrm{C}$ and $\mathrm{N}$ pools, $\mathrm{C}: \mathrm{N}$ ratios and microbial activities (Cheng et al., 2013; Deng et al., 2016). But study on N-hydrolyzing enzyme activities can be beneficial for understanding the interactions of soil -plant -microorganism for $\mathrm{N}$ cycling in this region. Thus, we hypothesized that: (1) afforestation would increase soil N-hydrolyzing enzyme activities primarily due to increased litter inputs (Zhou et al., 2020; Feng et al., 2018), while cultivation (i.e. cropland) would decrease soil N-hydrolyzing enzyme activities possibly due the addition of $\mathrm{N}$ fertilizer (Carlos et al., 2021; Zheng et al., 2020b); (2) microbial nutrient acquisition in afforested soils would be limited by $\mathrm{N}$ or/and $\mathrm{P}$ rather than by $\mathrm{C}$ likely due to the nutrients $(\mathrm{N}$ or/and $\mathrm{P}$ ) competition between plants and microbes (Zheng et al., 2020a). To test these hypotheses, we investigated seasonal patterns of NAG and LAP enzyme activities at the top $(0-10 \mathrm{~cm})$ and deep $(10-30 \mathrm{~cm})$ under land use change (i.e., woodland, shrubland, cropland and adjacent uncultivated fields). We also examined soil properties including soil moisture, temperature, $\mathrm{pH}$ and soil organic $\mathrm{C}$ and $\mathrm{N}$ (SOC and SON), labile N (LN) and recalcitrant N (RN).

\section{Materials and Methods}

\section{Study area and experimental design}

This study was conducted at the Wulongchi Experiment Station (32 $45^{\prime} \mathrm{N}, 111 \mathrm{deg} 13^{\prime} \mathrm{E}$; $280-400 \mathrm{~m}$ a.s.l) in the Danjiangkou Reservoir area, central China (Cheng et al., 2013). This area is a subtropical monsoon climate, with cold-dry winters and hot-humid summers. The mean annual precipitation is $749.3 \mathrm{~mm}$, with $70 \%-80 \%$ of the rain falls between April and October. The mean annual temperature is 15.7, with monthly maximum average temperature of 27.3in July and average minimum temperature of 4.2 in January (Wu et al., 2016). The soil is a yellow brown soil (according to Chinese soil classification system) with $11 \%$ sand, $41 \%$ silt, and $48 \%$ clay in the top $30 \mathrm{~cm}$ (Zhu et al., 2010). Human activities, such as tillage and deforestation, have caused water pollution, soil erosion and soil nutrient element losses around this reservoir (Zhu et al., 2010). Since 1980s, lager areas of uncultivated land around the reservoir have been converted to a woodland plantation of coniferous trees (Platycladus orientalis (Linn.) Franco) and a shrubland plantations (Sophora davidii (Franch.) Skeels) (Zhu et al., 2010). Cron (Zea mays (Linn.)) and rape (Brassica campestris (Linn.)) have been grown in rotation in cropland by conventional agricultural practices, including artificial weeding and chemical weeding, mineral fertilizations (approximately urea $375 \mathrm{~kg} \mathrm{ha}^{-1}$ and urine ammonium $200 \mathrm{~kg}$ $\mathrm{ha}^{-1}$ ) and plowing to a depth of $0.4 \mathrm{~m}$. The aboveground biomass of the corn straw and the rape was removed 
through harvesting.

The experimental design was a completely randomized complete block design containing four blocks/sites. Each block was approximately 3 ha $(600 \mathrm{mx} 50 \mathrm{~m})$ with $100 \mathrm{~m}$ buffer rows between two adjacent blocks. Four adjacent land types i.e., woodland, shrubland, cropland and uncultivated land (without any input of organic matter from trees and /or shrubs, i.e., the control) were included at each block. A comprehensive survey of soil and vegetation were conducted in October, 2016 to ensure the comparability (such as similar soil types and topographies) of the soil sampling plots among the four land types.

\section{Soil sampling and laboratory analysis}

Three soil sub-plots $(2 \mathrm{~m} \times 2 \mathrm{~m})$ were randomly selected in each land use type from four blocks for four times including October, 2016; January, 2017; April, 2017; July, 2017. Five soil cores (diameter $=5 \mathrm{~cm}$ ) from each sub-plot were randomly collected from two soil depths including $0-10 \mathrm{~cm}$ and $10-30 \mathrm{~cm}$. A total of 32 soil samples (three subplots in four plots with two soil layers) were collected to represent each land use type one season, with a grand total of 96 samples across all four land use types one season and with a grand total of 384 samples across all seasons. All the fresh soil samples were sieved with a $2 \mathrm{~mm}$ sieve after the visible plant material and stones were removed with forceps. Then, each soil sample was divided into two subsamples. One subsample was stored at -20 for the measurement of enzyme activities and PLFAs, the other subsample was air-dried for the soil physicochemical properties analyses.

Soil moisture was measured by oven-drying fresh soil at 105 to a constant weight. Soil pH was determined from soil water suspension (1:2.5 v: v) with a digital $\mathrm{pH}$ meter. The $\mathrm{C}$ and $\mathrm{N}$ concentrations was determined by the methods used by Rovira and Vallejo (2002). We used a two-step acid hydrolysis procedure to extractant to measure the labile and recalcitrant SOC, SON of bulk soil. Briefly, a portion of air-dried soil (approximately $2000 \mathrm{mg}$ ) was treated with $5 \mathrm{~mL} 1 \mathrm{~mol} / \mathrm{L} \mathrm{HCl}$ for $24 \mathrm{~h}$ to remove inorganic $\mathrm{C}$ for the measurements of soil organic carbon and nitrogen (SOC and SON). Then, soil recalcitrant N (RN) was obtained by acid hydrolysis. The SOC, SON and RN were analyzed by using an isotope ratio mass spectrometer (Thermo Finnigen, Delta- Plus, Flash, EA, 1112 Series, USA). Soil labile N (LN) is made by the difference between SON and RN. Soil N recalcitrance index (RIN) was calculated as follows (Cheng et al., 2013; Rovira and Vallejo, 2002):

$\mathrm{RIN}(\%)=\mathrm{RN} / \mathrm{SON}^{*} 100 \%$

Soil hydrolase activities, including N-acetyl- $\beta$-glucosaminidase (NAG), leucine aminopeptidase (LAP), $\beta$ glucosidase (BG) and phosphatase enzyme (AP) were determined by a fluorimetric microplate method (Deforest, 2009). The substrates used for enzyme assay were 4- MUB-N-acetyl- $\beta$-D-glucosaminide, t-Leucine7-amido-4-methylcoumarin and 4-methylumbelliferyl (MUB)- $\beta$-D-glucopyranoside for NAG and LAP, BG, respectively (Deforest, 2009). The BG, NAG and AP enzyme activities were measured using a modified fluorescent-linked substrate (4-methylumbelliferone (MUB) and the LAP enzyme activities were measure by fluorescent-linked substrate 7-Amino-4-methylcoumarin Chromophore (MUC) microplate protocol in situ pH conditions and temperature (Smith et al., 2015). Briefly, $1 \mathrm{~g}$ fresh soil was homogenized in $90 \mathrm{~mL}$ sodium tris buffer using a magnetic stirrer. Hydrolytic enzyme activities were measured fluorometrically in black polystyrene 96-well, 300-ml microplates (Whatman Inc., Florham Park, NJ). The dispensing of tris buffer, soil suspension, standard solution $(10 \mu \mathrm{M} 4$-MUB) and fluorescent substrate solution $(200 \mu \mathrm{M})$ specific to each enzyme followed a strict order on the well plate. The microplates were incubated in the dark at 25 for 3 hours. Following incubation, $10 \mu \mathrm{l}$ of $1 \mathrm{~mol} / \mathrm{L} \mathrm{NaOH}$ was added to stop the reaction and then the plates were read on a Beckman-Coulter DTX880 fluorescent microplate reader with excitation of $360 \mathrm{~nm}$ and emission of $450 \mathrm{~nm}$ (Beckman-Coulter, Fullerton, CA, USA). Enzyme activities were expressed as nmol fluorescene $\mathrm{g}^{-1}$ dry fraction $\mathrm{h}^{-1}$. Specific enzyme activities (i.e. enzyme activities per unit of SON) were calculated by dividing enzyme activities over the SON (Raiesi and Beheshti, 2014).

We used phospholipid fatty acids (PLFAs) to determine total PLFAs and ratios of fungal to bacterial biomass (F: B ratios) (Bossio and Scow, 1998). Briefly, total lipids were extracted using $23 \mathrm{~mL}$ extraction mixture [chloroform: methanol: phosphate buffer $(1: 2: 0.8 \mathrm{v} / \mathrm{v} / \mathrm{v})$ ] from $8 \mathrm{~g}$ of lyophilized soil. Samples containing 
nonadecanoic acid methyl ester (19:0) as an internal standard were analyzed with an Agilent 6890 Gas Chromatograph equipped with an Ultra 2-methylpolysiloxane column.

\section{Statistics}

Soil N-hydrolyzing enzyme activities in soil were normalized to SON concentration (enzyme: SON) to analyze the specific enzyme activities. Multiple-way Analysis of Variance (ANOVA) was used to test the statistical significance of land use types, seasons, depths and their interactive effects on soil variables (two N-hydrolyzing enzyme activities). One-way ANOVA with Tukey's HSD test was used to further test the statistical significance of land use types, seasons, depths on soil enzyme activities, respectively. Analysis for all of the data was carried out using IBM SPSS Statistics 21.0 software (Armonk, NY, USA). The Pearson correlation coefficients using IBM SPSS Statistics 21.0 and redundancy analysis (RDA) using Canoco5.0 were performed to quantify the correlations between soil enzyme activities and soil variables. The significance level was established at $\mathrm{p}<0.05$. Soil C-, N- and P-hydrolyzing enzyme activities were loge-transformed prior to stoichiometric analyses following the conventions of stoichiometric studies and to better achieve normality (Sterner and Elser 2002; Sinsabaugh et al., 2009)

\section{Results}

Soil enzyme activities

Generally, the mean NAG and LAP enzyme activities increased from the uncultivated land to cropland to afforested lands (shrubland and woodland) with higher levels in the top soil than deep soil (Fig. 1). The seasonal patterns of NAG and LAP enzyme activities showed higher levels in summer compared to other seasons in all land use types except the cropland with lower level of NAG enzyme activity in summer at the top soil (Fig. 2). The mean specific enzyme activities for two N-hydrolyzing enzymes were significantly lower in the uncultivated soils than other land use types at both soil layers except in the shrubland of deep soil (Fig. 3). Notably, two specific enzyme activities were higher in the top soil than deep soil, but there were no significant differences in two specific enzyme activities between top soil and deep soil in the woodland (Fig. $3)$.

Enzyme C: N: P stoichiometry

The mean soil ecoenzymatic C: N, C: P ratios increased from the uncultivated to afforested lands to cropland at both two soil depths (Fig. $4 \mathrm{a}, \mathrm{b}$ ). The mean soil ecoenzymatic N: P ratios were significantly higher in the cropland than other soil types at both two soil depths (Fig. 4c). There was no significant difference in soil ecoenzymatic N: P ratios between the uncultivated land and afforested lands at top soil, while the soil ecoenzymatic N: P ratios were significantly lower in the afforested lands than uncultivated land at deep soil (Fig. 4c). The mean soil ecoenzymatic C: N, C: P, N: P ratios were significantly higher in the top soil than deep soil in the cropland and afforested land except ecoenzymatic N: P ratio in the cropland, but there were no significant differences in soil ecoenzymatic C: N, C: P, N: P ratios between top soil and deep soil in the uncultivated land (Fig. 4). Notably, all the soil ecoenzymatic C: N, C: P and N: P ratios were less than 1 (Fig. 4), and mean ecosystem ratios of C: N: P hydrolyzing enzyme activities [i.e. the ratio of (BG): $\ln$ (NAG + LAP): ln (AP)] ranged from 1: 1.06: 1.12 to 1: 2.20: 2.50 in all land use types (Table 3).

Key factors affecting soil enzyme activities and C: N: P stoichiometry

The Pearson correlation analysis showed that two N- hydrolyzing enzymes (NAG, LAP) activities were significantly related to soil $\mathrm{N}$ and $\mathrm{C}$ contents [SON, SOC, LN, RN, C: $\mathrm{N}$ ratio of organic soil, $\mathrm{C}$ : $\mathrm{N}$ ratio of labile pool, C: $\mathrm{N}$ ratio of recalcitrant soil, $\mathrm{RIN}, \mathrm{NH}_{4}{ }^{+}-\mathrm{N}, \mathrm{NO}_{3}{ }^{-}-\mathrm{N}$ ), they were also significantly positively correlated with soil total PL FAs and negatively correlated with the F: B ratios (Table 1). The RDA showed that there was a significant relationship between the soil enzyme activities and environment factors $(\mathrm{F}=$ $117, p=0.002$, Fig. 5). The abiotic and biotic factors (i.e., SON, SOC, C: N ratio of organic soil, RIN, $\mathrm{NH}_{4}{ }^{+}-\mathrm{N}, \mathrm{NO}_{3}{ }^{-}-\mathrm{N}$, total PLFAs, F: B ratios, moisture, temperature, $\mathrm{pH}$ ) together explained $96.13 \%$ of the total variability in the soil enzyme activities (axis 1,96.62\%; axis 2, 1.51\%) (Fig. 5a).The environmental factors (i.e., C: $\mathrm{N}$ ratio of organic soil, C: $\mathrm{N}$ ratio of labile pool, C: $\mathrm{N}$ ratio of recalcitrant pool, $\mathrm{RIN} \mathrm{NH}_{4}{ }^{+}-\mathrm{N}$, 
$\mathrm{NO}_{3}{ }^{-}-\mathrm{N}$, total PLFAs, F: B ratios, moisture, temperature and $\mathrm{pH}$ ) explained $96.13 \%$ of the total variability in the soil enzyme activities (axis 1, 96.46\%; axis 2, 1.49\%) (Fig. 5b).

Soil enzyme C: N ratio and soil enzyme C: P ratio had a positive relationship with SON, SOC, LN, RN, C: N ratio of recalcitrant pool, and total PLFAs had a negative relationship with $\mathrm{RIN}, \mathrm{NH}_{4}{ }^{+}-\mathrm{N}, \mathrm{F}$ : B ratios, $\mathrm{pH}$. Soil enzyme N: P ratios were positively correlated with $\mathrm{NO}_{3}{ }^{-}-\mathrm{N}$, soil moisture and were negatively correlated with $\mathrm{F}$ : $\mathrm{B}$ ratios and $\mathrm{pH}$ (Table 1).

\section{Discussion}

Our results demonstrated that soil N- hydrolyzing enzyme activities (including NAG and LAP), and the specific enzyme activities varied with land use change and season in the Danjiangkou Reservoir area of central China (Table 2; Figs. 1-3). Notably, whether conversion of uncultivated land to the afforested lands (woodland and shrubland) or cropland enhanced NAG and LAP enzyme activities in this region. With land use changing, multiple factors including availability of nutrients, soil microbial attributes and soil properties could cause variation in soil enzyme activities and EES (Luo et al., 2020; Zhao et al., 2018).

Firstly, greater SOC and SON contents in afforested soils and cropland soils compared to the uncultivated land (Table 1; Fig. 5) made larger contribution to increases in NAG and LAP enzyme activities, because SOC and SON could provide more substrates and energy for enzymatic reactions (Feng et al., 2018). The significant positive relationships of soil N-hydrolyzing enzyme activities with SON, SOC (Table 1; Table S1) further confirmed that the SON and SOC were importance source for microbes producing hydrolytic enzymes (Wallenstein \& Weintraub, 2008; Yu et al., 2017). Increased N-hydrolyzing enzyme activities in the afforested soils could also be attributed to larger LN contents as labile organic matter were preferentially used by microorganisms (Knops et al., 2002). The tightly positive relationship between LN and hydrolyzing enzyme activities were found in our Pearson's correlation analysis (Table 1). Secondly, the higher soil C: N ratios (i.e., the C: $\mathrm{N}$ ratio of organic soils, C: $\mathrm{N}$ ratio of labile pool, C: $\mathrm{N}$ ratio of recalcitrant pool) could possibly lead to higher N-hydrolyzing enzyme activities as microbial activities was more susceptible to $\mathrm{N}$ restriction (Mendham et al., 2004). This speculation was supported by the significant positive correlation between soil N-hydrolyzing enzyme activities and three kinds of C: $\mathrm{N}$ ratios across all land types (Table 1). Thirdly, our results showed that two N- hydrolyzing enzyme activities was negatively correlated with $\mathrm{NH}_{4}{ }^{+}-\mathrm{N}$ and $\mathrm{NO}_{3}{ }^{-}-\mathrm{N}$ (Table 1). This result also agrees with the results of other researchers, which showed that increased inorganic $\mathrm{N}$ availability could inhibit the synthesis of $\mathrm{N}$-hydrolyzing enzyme activities (Allison et al., 2007; Stursova et al., 2006). Additionally, our results showed that change in soil pH under land use change negatively affected soil N-hydrolyzing enzyme activities (Table 1 and Table S1), which highlighted the evidence that soil $\mathrm{pH}$ was a strong control on enzyme activities with soil $\mathrm{pH}$ values of approximately 8 (Cenini et al., 2016).

As expect, part of our finding was consistent with our hypothesis 1 that afforestation would increase soil N-hydrolyzing enzyme activities compared with uncultivated soils. Whereas, cultivation also increased soil N-hydrolyzing enzyme activities compared with those in the uncultivated land soil, which was contrary to part of the hypothesis 1 (Figs. 1-2). This could attribute to the $\mathrm{N}$ fertilization could not meet the nutritional needs of crops and microorganisms in cropland. Generally, N- hydrolyzing enzyme activities decreased with the soil depth (Figs. 1-2), primarily due to the decrease in $\mathrm{C}$ and $\mathrm{N}$ availability with increasing soil depth (Bowles et al., 2014). Meanwhile, the seasonal pattern of both NAG and LAP enzyme activities with higher levels in summer than other seasons could be attributed to higher microbial biomass in summer (Fig. 2). Globally, temperature has positive influence on the activities of N-hydrolyzing enzymes (Sinsabaugh et al., 2008). However, there was no significant relationship between soil temperature and soil N-hydrolyzing enzyme activities in our study region (Table 1). Instead, we found the positive relationship between soil total PLFA biomass and soil NAG and LAP enzyme activities (Table 1), due to more favorable temperature in summer (Zhang et al., 2016; Zhang et al., 2019a; Table 1)

Specific enzyme activities increased with both cultivation and afforestation (Fig. 3), confirming that increased $\mathrm{N}$ turnover rate and enhanced $\mathrm{N}$ mineralization via $\mathrm{N}$-hydrolyzing enzyme activities (Wang et al., 2012). It 
has been suggested that specific enzyme activities can decouple the soil enzyme activities from changes in SON contents, which can serve as an improved indicator of the co-metabolism of microbial communities (Raiesi and Beheshti 2014; Sinsabaugh et al., 2009). We also found specific enzyme activities were significantly lower in cropland compared to afforested soils (Fig. 3), being consistent with previous results that $\mathrm{N}$ fertilization in cropland reduced the activity of NAG and LAP per unit of soil SON (Cenini, 2016). The addition of inorganic forms of $\mathrm{N}$ to soils could provide $\mathrm{N}$ forms available for microorganism to be assimilated, which could explain the lower N-hydrolyzing enzyme activities and lower specific enzyme activities in cropland compared to the afforested lands.

Previous studies indicated that soil ecoenzymatic C: N, C: P and N: P ratios reflected the metabolic requirements and nutrient availability of microbes in the environments (Cui et al., 2018; Waring et al., 2014). The soil ecoenzymatic C: $\mathrm{N}$ and C: P ratios were averaged 0.72 and 0.63 in our dataset, respectively (Fig. 4), which was higher than the global values (0.62 and 0.13) (Sinsabaugh et al., 2008, 2009). This finding implied that soil microbial growth and $\mathrm{C}$ uptake in our study area could be limited by $\mathrm{N}$ and $\mathrm{P}$ availability (Xu et al., 2017). Peng and Wang (2016) also reported higher soil ecoenzymatic N: P ratio in temperate grasslands than in tropical soils, indicating higher $\mathrm{N}$ demand compared to $\mathrm{P}$ demand in temperate grassland. Meanwhile, we found that soil ecoenzymatic C: N and C: P ratios were higher in the afforested lands and croplands than in the uncultivated land, indicating that greater microbial demand for $\mathrm{C}$ relative to $\mathrm{N}$ and $\mathrm{P}$ with afforestation and cultivation. Higher soil ecoenzymatic C: N and C: P ratios in cropland land and afforested land could be related to the different nutrient status of soil microorganism (He et al., 2020). According to resource allocation strategy, microbes produce additional N-hydrolyzing enzymes (indicated by low soil ecoenzymatic C: $\mathrm{N}$ ratios) in nutrient-limited environments (Xu et al., 2017). However, the soil ecoenzymatic C: $\mathrm{N}$ ratios increased with increasing soil C: $\mathrm{N}$ ratios in this present study (Table 1). We inferred that the enzymatic acquisition did not match the resource stoichiometry because SOM with labile and recalcitrant fractions, possibly only a small labile fraction could be used by microorganisms (Kamble and Bååth, 2014). This speculation was supported by the higher RIC and RIN index (i.e. larger recalcitrant fraction) in afforested soils (Table 1 ).

In addition, we found that soil ecoenzymatic N: $\mathrm{P}$ ratio was significantly higher in cropland than other land uses (Fig. 4), due to $\mathrm{P}$ fertilizer in cropland. During afforestation, plant debris input in woodland and shrubland, possibly increased soil $\mathrm{N}$ content (Cheng et al., 2013; Zhang et al., 2016), while soil $\mathrm{P}$ was mainly derived from mineral decomposition and fertilizer. The addition of $\mathrm{P}$ fertilizer to farmland could weaken the $\mathrm{P}$ limitation. All ecoenzymatic ratios (ecoenzymatic C: $\mathrm{N}$ ratios, ecoenzymatic C: $\mathrm{P}$ ratios and ecoenzymatic $\mathrm{N}$ : P ratios) decreased with depth in afforested soils, suggesting that microbes could invest more N- and P-hydrolyzing enzymes than C-hydrolyzing enzymes, especially in deep soils. Notably, soil enzymatic C: N: P hydrolyzing enzyme activities averaged from 1: 1.06: 1.12 to 1: 2.20: 2.50 in all land use types (Table 3). The ratios of soil C-, N-, and P-hydrolyzing enzyme activities converged on 1:1:1 at the global scale, that defined the boundaries of microbial responses to changes in resource availability and resource allocation patterns depending on nutrient demands (Sinsabaugh et al., 2008). Thus, our results significantly deviated from 1:1:1. It indicated that soil microbes were co-limited by $\mathrm{C}$ and $\mathrm{P}$ with the imbalance between resource supply and production $\mathrm{N}$ and $\mathrm{P}$ limitation in our study region.

\section{Conclusion}

This research evaluated nutrient limitation of soil microbial communities during land use change from the perspective of microbial metabolisms around the Danjiangkou Reservori area of central China. Conversion of uncultivated land to woodland, shrubland plantations or cropland in this region stimulated soil $\mathrm{N}$ cycling via increased N-hydrolyzing enzyme activities and specific enzyme activities. High $\mathrm{C}$ and $\mathrm{N}$ contents were the major controls on higher N-hydrolyzing enzyme activities under afforestation and cultivation. Soil temperature was an important factor in regulating the seasonal variations in enzyme activities. Although microbial nutrient metabolisms were co-limited by $\mathrm{N}$ and $\mathrm{P}$, especially $\mathrm{P}$ across all land use types, $\mathrm{N}$ and $\mathrm{P}$ limitation were decreased with cultivation and afforestation. The nutrient limitation of microbial metabolisms strongly depended on the contents and stoichiometries of the soil nutrients. Overall, these findings suggested that the 
coupling of soil enzyme stoichiometry and nutrient status to reveal soil microbial metabolic limitation and nutrient cycling under global land use change.

\section{Acknowledgments}

This research was financially supported by the National Natural Science Foundation of China (31770563). We thank Fan Yang, Qiong Cheng and Chunyan Long for their assistances in the laboratory analyses.

\section{Reference}

Acosta-Martínez, V., Cruz, L., Sotomayor-Ramírez, D. \& Pérez-Alegría, L. (2007). Enzyme activities as affected by soil properties and land use in a tropical watershed. Applied Soil Ecology , 35, 35-45. DOI: 10.1016/j.apsoil.2006.05.012

Allison, S.D., Czimczik, C.I. \& Treseder, K.K. (2008). Microbial activity and soil respiration under nitrogen addition in Alaskan boreal forest. Global Change Biology , 14, 1156-1168. DOI: 10.1111/j.13652486.2008.01549.x

Bossio, D.A. \& Scow, K.M. (1998). Impacts of carbon and flooding on soil microbial communities: phospholipid fatty acid profiles and substrate utilization patterns. Microbial Ecology , 35, 265-278. DOI: $10.1007 / \mathrm{s} 002489900082$

Bowles, T.M., Acosta-Martínez, V., Calderón, F. \& Jackson, L.E. (2014). Soil enzyme activities, microbial communities, and carbon and nitrogen availability in organic agroecosystems across an intensively-managed agriculture landscape. Soil Biology Biochemisty 68, 252-262. DOI: 10.1016/j.soilbio.2013.10.004

Cenini, V.L., Fornara, D.A., McMullan, G., Ternan, N., Carolan, R., Crawley, M.J., Clément J-C. \& Lavorel, S. (2016). Linkages between extracellular enzyme activities and the carbon and nitrogen content of grassland soils. Soil Biology Biochemistry, 96, 198-206. DOI: 10.1016/j.soilbio.2016.02.015

Cheng X., Yang, Y., Li, M., Dou, X. \& Zhang, Q. (2013). The impact of agricultural land use changes on soil organic carbon dynamics in the Danjiangkou Reservoir area of China. Plant and Soil , 366, 415-424. DOI: 10.1007/s11104-012-1446-6

Carlos, F.S., Schaffer, N., Marcolin, E., Fernandes, R.S., Mariot, R., Mazzurana, M., Roesch, L.F.W., Levandoski, B., Oliveira Camargo, F.A. (2021). Long term no tillage system can increase enzymatic activity and maintain bacterial richness in paddy field. Land Degradation \& Development. DOI: 10.1002/ldr.3896

Cui, Y., Fang, L., Guo, X., Wang, X., Zhang, Y., Li, P. \& Zhang, X. (2018). Ecoenzymatic stoichiometry and microbial nutrient limitation in rhizosphere soil in the arid area of the northern Loess Plateau, China.Soil Biology Biochemistry, 116, 11-21. DOI: 10.1016/j.soilbio.2017.09.025

DeForest, J.L. (2009). The influence of time storage temperature and substrate age on potential soil enzyme activity in acidic forest soils using MUB-linked substrates and L-DOPA. Soil Biology Biochemistry, 41, 1180-1186. DOI: 10.1016/j.soilbio.2009.02.029

DeForest, J.L. \& Moorhead, D.L. (2020). Effects of elevated pH and phosphorus fertilizer on soil C., N and P enzyme stoichiometry in an acidic mixed mesophytic deciduous forest. Soil Biology Biochemistry, 150. DOI: 10.1016/j.soilbio.2020.107996

Deng, Q., Cheng, X., Hui, D., Zhang, Q., Li, M. \& Zhang, Q. (2016). Soil microbial community and its interaction with soil carbon and nitrogen dynamics following afforestation in central China.Science of the Total Environment, 541, 230-237. DOI: 10.1016/j.scitotenv.2015.09.080

Feng, J., Wu, J., Zhang, Q., Zhang, D., Li, Q., Long, C., Yang, F., Chen Q. \& Cheng, X. (2018). Stimulation of nitrogen-hydrolyzing enzymes in soil aggregates mitigates nitrogen constraint for carbon sequestration following afforestation in subtropical China. Soil Biology Biochemistry, 123, 136-144. DOI: 10.1016/j.soilbio.2018.05.013 
Guo, Z., Zhang, X., Green, S.M., Dungait, J.A.J., Wen, X., Quine, T.A. (2019). Soil enzyme activity and stoichiometry along a gradient of vegetation restoration at the Karst Critical Zone Observatory in Southwest China. Land Degradation 83 Development , 30, 1916-1927. DOI: 10.1002/ldr.3389

He, Q., Wu, Y., Bing, H., Zhou, J. \& Wang, J. (2020). Vegetation type rather than climate modulates the variation in soil enzyme activities and stoichiometry in subalpine forests in the eastern Tibetan Plateau.Geoderma , 374. DOI: 10.1016/j.geoderma.2020.114424

Knops, J.M.H., Bradley, K.L. \& Wedin, D.A. (2002). Mechanisms of plant species impacts on ecosystem nitrogen cycling. Ecology Letters,5, 454-466. DOI: 10.1046/j.1461-0248.2002.00332.x

Luo, D., Cheng, R., Liu, S., Shi, Z. \& Feng, Q. (2020). Responses of Soil Microbial Community Composition and Enzyme Activities to Land-Use Change in the Eastern Tibetan Plateau, China. Forests, 11(5). DOI: 10.3390/f11050483.

Mendham, D.S., Heagne, E.C., Corbeels, M., O'Connell, A.M., Grove, T.S. \& McMurtrie, R.E. (2004). Soil particulate organic matter effects on nitrogen availability after afforestation with Eucalyptus globulus.Soil Biology Biochemistry, 36, 1067-1074. DOI: 10.1016/j.soilbio.2004.02.018

Mbuthia, L.W., Acosta-Martínez, V., DeBruyn, J., Schaeffer, S., Tyler, D., Odoi, E., Mpheshea, M., Walker, F. \& Eash, N. (2015). Long term tillage, cover crop, and fertilization effects on microbial community structure, activity: Implications for soil quality. Soil Biology Biochemistry, 89, 24-34. DOI: 10.1016/j.soilbio.2015.06.016

Moscatelli, M., Secondi, L., Marabottini, R., Pap, R., Stazi, S., Mania, E. \& Marinari, S. (2018). Assessment of soilmicrobial functional diversity: Land use and soil properties affect CLPP-MicroResp and enzymes responses. Pedobiologia, 66, 36-42. DOI:10.1016/j.pedobi.2018.01.001

Peng, X. \& Wang, W. (2016). Stoichiometry of soil extracellular enzyme activity along a climatic transect in temperate grasslands of northern China. Soil Biology Biochemistry, 98, 74-84. DOI: 10.1016/j.soilbio.2016.04.008

Pinsonneault, A.J., Moore, T.R. \& Roulet, N.T. (2016). Temperature the dominant control on the enzyme-latch across a range of temperate peatland types. Soil Biology Biochemistry, 97, 121-130. DOI: 10.1016/j.soilbio.2016.03.006

Raiesi, F. \& Beheshti, A. (2014). Soil specific enzyme activity shows more clearly soil responses to paddy rice cultivation than absolute enzyme activity in primary forests of northwest Iran. Applied Soil Ecology, 75, 63-70. DOI: $10.1016 /$ j.apsoil.2013.10.012

Rovira, P. \& Vallejo, V.R. (2002). Labile and recalcitrant pools of carbon and nitrogen in organic matter decomposing at different depths in soil: an acid hydrolysis approach. Geoderma, 107, 109-41. DOI: 10.1016/S0016-7061(01)00143-4

Schimel, J. (2003). The implications of exoenzyme activity on microbial carbon and nitrogen limitation in soil: a theoretical model. Soil Biology Biochemistry, 35, 549-563. DOI: 10.1016/S0038-0717(03)00015-4

Schimel, J., Becerra, C.A. \& Blankinship, J. (2017). Estimating decay dynamics for enzyme activities in soils from different ecosystems. Soil Biology Biochemistry, 114, 5-11. DOI: 10.1016/j.soilbio.2017.06.023

Sinsabaugh, R.L. \& Follstad, Shah J.J., 2012. Ecoenzymatic Stoichiometry and Ecological Theory. Annual Review of Ecology, Evolution, and Systematics, 43, 313-343. DOI: 10.1146/annurev-ecolsys-071112-124414

Sinsabaugh, R.L., Hill, B.H., Follstad Shah, J.J. (2009). Ecoenzymatic stoichiometry of microbial organic nutrient acquisition in soil and sediment. Nature 462, 795-798. DOI: 10.1038/nature08632

Sinsabaugh, R.L., Lauber, C.L., Weintraub, M.N., Ahmed, B., Allison, S.D., Crenshaw, C., Contosta, A.R., Cusack, D., Frey, S., Gallo, M.E., Gartner T B., Hobbie S E., Holland K., Keeler B L., Powers J S., Stursova M., Takacs-Vesbach, C., Waldrop, M.P., Wallenstein, M.D., Zak, D.R. \& Zeglin, L.H. (2008). 
Stoichiometry of soil enzyme activity at global scale. Ecology Letters , 11, 1252-1264. DOI: 10.1111/j.14610248.2008.01245.x

Smith, A.P., Marin-spiotta, E. \& Balser, T. (2015). Successional and seasonal variations in soil and litter microbial community structure and function during tropical post agricultural forest regeneration: a multiyear study. Global Change Biology, 21, 3532-3547. DOI: 10.1111/gcb.12947

Song, X.P., Hansen, M.C., Stehman, S.V., Potapov, P.V., Tyukavina, A., Vermote, E.F. \& Townshend, J.R. (2018). Global land change from 1982 to 2016. Nature, 560, 639-643. DOI: 10.1038/s41586-018-0411-9

Wallenstein, M. D., \& Weintraub, M. N. (2008). Emerging tools for measuring and modeling the in situ activity of soil extracellular enzymes. Soil Biology \& Biochemistry, 40, 2098-2106. https://doi.org/10.1016/j.

soilbio.2008.01.024 Wang, B., Xue, S., Liu, G.B., Zhang, G.H., Li, G. \& Ren, Z.P. (2012). Changes in soil nutrient and enzyme activities under different vegetations in the Loess Plateau area Northwest China. Catena , 92, 186-195. DOI: 10.1016/j.catena.2011.12.004

Wu, J., Zhang, Q., Yang, F., Lei., Zhang, Q. \& Cheng, X. (2016). Afforestation impacts microbial biomass and its natural ${ }^{13} \mathrm{C}$ and ${ }^{15} \mathrm{~N}$ abundance in soil aggregates in central China. Science of The Total Environment,568, 52-56. DOI: 10.1016/j.scitotenv.2016.05.224

Xu, Z., Yu, G., Zhang, X., He, N., Wang, Q., Wang, S., Wang, R., Zhao, N., Jia, Y. \& Wang, C. (2017). Soil enzyme activity., stoichiometry in forest ecosystems along the North-South Transect in eastern China (NSTEC). Soil Biology Biochemistry, 104, 152-163. DOI: 10.1016/j.soilbio.2016.10.020

Yang, Y., Liang, C., Wang, Y., Cheng, H., An, S. \& Chang, S.X. (2020). Soil extracellular enzyme stoichiometry reflects the shift from P- to N-limitation of microorganisms with grassland restoration. Soil Biology Biochemistry, 149. DOI: 10.1016/j.soilbio.2020.107928

Yu, P., Liu, S., Han, K., Guan, S. \& Zhou, D. (2017). Conversion of cropland to forage land and grassland increases soil labile carbon and enzyme activities in northeastern China. Agriculture, Ecosystems $\mathcal{G}^{3}$ Environment, 245, 83-91. DOI: 10.1016/j.agee.2017.05.013

Yue, C., Ciais, P., Houghton, R.A. \& Nassikas A.A. (2020). Contribution of land use to the interannual variability of the land carbon cycle.Nature Communication , 11, 3170. DOI: 10.1038/s41467-020-16953-8

Zhang, Q., Feng, J., Wu, J., Zhang, D., Chen, Q., Li, Q., Long, C., Feyissa, A. \& Cheng, X., (2019a). Variations in carbon-decomposition enzyme activities respond differently to land use change in central China. Land Degradation and Development , 30 459-469. DOI: 10.1002/ldr.3240

Zhang, Q., Wu, J., Yang, F., Lei, Y., Zhang, Q. \& Cheng, X. (2016). Alterations in soil microbial community composition and biomass following agricultural land use change. Scientific Reports, 6, 36587. DOI: $10.1038 /$ srep36587

Zhang, W., Xu, Y., Gao, D., Wang, X., Liu, W., Deng, J., Han, X., Yang, G., Feng, Y. \& Ren, G. (2019b). Ecoenzymatic stoichiometry and nutrient dynamics along a revegetation chronosequence in the soils of abandoned land and Robinia pseudoacacia plantation on the Loess Plateau, China.Soil Biology Biochemistry, 134, 1-14. DOI: 10.1016/j.soilbio.2019.03.017

Zhao, F.Z., Ren, C.J., Han, X.H., Yang, G.H., Wang, J. \& Doughty, R. (2018). Changes of soil microbial and enzyme activities are linked to soil $\mathrm{C}, \mathrm{N}$ and $\mathrm{P}$ stoichiometry in afforested ecosystems. Forest Ecology Management, 427, 289-295. DOI: 10.1016/j.foreco.2018.06.011

Zheng, L., Chen, H., Wang, Y., Mao, Q., Zheng, M., Su, Y., Xiao, K., Wang, K. \& Li, D. (2020a). Responses of soil microbial resource limitation to multiple fertilization strategies. Soil and Tillage Research, 196. DOI: 10.1016/j.still.2019.104474

Zheng, W., Gong, Q., Lv, F., Yin, Y., Li, Z. \& Zhai, B. (2020b). Tree-scale spatial responses of extracellular enzyme activities and stoichiometry to different types of fertilization and cover crop in an apple orchard. 
European Journal of Soil Biology, 99. DOI: 10.1016/j.ejsobi.2020.103207

Zhou, L., Liu, S., Shen, H., Zhao, M., Xu, L., Xing, A., Fang, J. \& Sayer, E. (2020). Soil extracellular enzyme activity and stoichiometry in China's forests. Function Ecology, 34, 1461-1471. DOI: 10.1111/13652435.13555

Zhu, M.Y., Tan, S.D., Gu, S. \& Zhang, Q.F. (2010). Characteristics of soilerodibility in the Danjiangkou Reservoir Region Hubei Province.Chinese Journal of Soil Science, 41, 434-436. DOI: $10.1080 / 00949651003724790$

Table 1 Pearson correlation coefficients of soil enzyme activity on soil properties across soil depths, seasons and land use types $\left({ }^{*} p<0.05 ; ;^{* *} p<0.01 ;{ }^{* * *} p<0.001\right.$; NS, no significant; numbers are F-values $)$.

\begin{tabular}{|c|c|c|c|c|c|}
\hline & NAG & LAP & $\begin{array}{l}\text { Ecoenzymatic C: } \\
\mathrm{N} \text { ratios }\end{array}$ & $\begin{array}{l}\text { Ecoenzymatic C: } \\
\text { P ratios }\end{array}$ & $\begin{array}{l}\text { Ecoenzymatic N: } \\
\text { P ratios }\end{array}$ \\
\hline$\overline{\mathrm{SON}}$ & $0.81^{* *}$ & $0.80^{* *}$ & $0.45^{* *}$ & $0.40^{* *}$ & NS \\
\hline $\mathrm{SOC}$ & $0.85^{* *}$ & $0.82^{* *}$ & $0.37^{* *}$ & $0.31^{* *}$ & NS \\
\hline $\begin{array}{l}\mathrm{C}: \mathrm{N} \text { ratio of } \\
\text { organic soil }\end{array}$ & $0.85^{* *}$ & $0.76^{* *}$ & $0.32^{* *}$ & NS & NS \\
\hline $\mathrm{LN}$ & $0.81^{* *}$ & $0.80^{* *}$ & $0.40^{* *}$ & $0.35^{* *}$ & NS \\
\hline $\begin{array}{l}\text { C: } \mathrm{N} \text { ratio of } \\
\text { labile pool }\end{array}$ & $0.37^{* *}$ & $0.28^{* *}$ & NS & NS & NS \\
\hline RN & $0.70^{* *}$ & $0.72^{* *}$ & $0.49^{* *}$ & $0.46^{* *}$ & NS \\
\hline $\begin{array}{l}\mathrm{C}: \mathrm{N} \text { ratio of } \\
\text { recalcitrant } \\
\text { pool }\end{array}$ & $0.83^{* *}$ & $0.77^{* *}$ & $0.33^{* *}$ & $0.26^{* *}$ & NS \\
\hline RIN & $-0.78^{* *}$ & $-0.75^{* *}$ & $-0.42^{* *}$ & $-0.34^{* *}$ & NS \\
\hline $\mathrm{NH}_{4}{ }^{+}-\mathrm{N}$ & $-0.53^{* *}$ & $-0.58^{* *}$ & $-0.74^{* *}$ & $-0.71^{* *}$ & NS \\
\hline $\mathrm{NO}_{3}^{-}-\mathrm{N}$ & $-0.41^{* *}$ & NS & NS & NS & $0.35^{* *}$ \\
\hline Total PLFAs & $0.92^{* *}$ & $0.94^{* *}$ & $0.53^{* *}$ & $0.48^{* *}$ & NS \\
\hline $\mathrm{F}: \mathrm{B}$ & $-0.17^{*}$ & $-0.27^{* *}$ & $-0.36^{* *}$ & $-0.39^{* *}$ & $-0.25^{* *}$ \\
\hline SM & 0.11 & -0.97 & NS & NS & NS \\
\hline $\mathrm{ST}$ & 0.9 & 0.16 & NS & $0.20^{*}$ & $0.28^{* *}$ \\
\hline $\mathrm{pH}$ & $-0.50^{* *}$ & $-0.56^{* *}$ & $-0.66^{* *}$ & $-0.66^{* *}$ & $-0.25^{* *}$ \\
\hline
\end{tabular}

Note : NAG, N-acetyl- $\beta$-glucoasminidase enzyme; LAP, leucine aminopeptidase enzyme; BG, $\beta$-glucosidase; AP, phosphatase enzyme; SON, soil organic nitrogen; SOC, soil organic carbon; LN, soil labile nitrogen; RN, soil recalcitrant nitrogen; RIN; recalcitrant nitrogen index; SM, soil moisture; ST, soil temperature.

Table 2Statistical significance of the effects of land use types, seasons, depths and their interactions on soil enzyme activities based on Multiple ANOVA (NS = not significant; ${ }^{*} p<0.05 ;{ }^{* *} p<0.01 ;{ }^{* * *} p<0.001$, NS, no significant; numbers are F-values).

\begin{tabular}{llllllll}
\hline & & $\begin{array}{l}\text { Land use } \\
\text { type }(\mathrm{L})\end{array}$ & $\begin{array}{l}\text { Depth }(\mathrm{cm}) \\
(\mathrm{D})\end{array}$ & $\mathrm{T} \times \mathrm{L}$ & $\mathrm{T} \times \mathrm{D}$ & $\mathrm{L} \times \mathrm{D}$ & $\mathrm{T} \times \mathrm{L} \times \mathrm{D}$ \\
\hline NAG & $34.72^{* * *}$ & $246.50^{* * *}$ & $190.27^{* * *}$ & $10.33^{* * *}$ & $3.89^{*}$ & $32.74^{* * *}$ & $2.47^{* *}$ \\
LAP & $76.11^{* * *}$ & $251.17^{* * *}$ & $428.777^{* * *}$ & $13.59^{* * *}$ & $\mathrm{NS}$ & $52.61^{* * *}$ & $\mathrm{NS}$ \\
$\mathrm{AP}$ & $41.84^{* * *}$ & $626.97^{* * *}$ & $420.85^{* * *}$ & $12.98^{* * *}$ & $10.41^{* * *}$ & $72.40^{* * *}$ & $7.00^{* * *}$ \\
Ecoenzymatic & $126.91^{* * *}$ & $293.70^{* * *}$ & $348.69^{* * *}$ & $44.86^{* * *}$ & $9.50^{* * *}$ & $6.73^{* * *}$ & $8.19^{* * *}$ \\
C: N & & & & & & & \\
ratios & & & & & & &
\end{tabular}




\begin{tabular}{|c|c|c|c|c|c|c|c|}
\hline & Time $(\mathrm{T})$ & $\begin{array}{l}\text { Land use } \\
\text { type (L) }\end{array}$ & $\begin{array}{l}\text { Depth }(\mathrm{cm}) \\
\text { (D) }\end{array}$ & $\mathrm{T} \times \mathrm{L}$ & $\mathrm{T} \times \mathrm{D}$ & $\mathrm{L} \times \mathrm{D}$ & $\mathrm{T} \times \mathrm{L} \times \mathrm{D}$ \\
\hline $\begin{array}{l}\text { Ecoenzymatic } \\
\text { C: } \mathrm{P} \\
\text { ratios }\end{array}$ & $188.55^{* * *}$ & $404.05^{* * *}$ & $520.63^{* * *}$ & $38.61^{* * *}$ & $12.24^{* * *}$ & $16.19^{* * *}$ & $7.93^{* * *}$ \\
\hline $\begin{array}{l}\text { Ecoenzymatic } \\
\mathrm{N}: \mathrm{P} \\
\text { ratios }\end{array}$ & $16.80^{* * *}$ & $85.71^{* * *}$ & $46.71^{* * *}$ & $4.51^{* * *}$ & $4.91^{* *}$ & $15.75^{* * *}$ & NS \\
\hline
\end{tabular}

Note : See Table1 for abbreviations.

Table 3 Mean ecosystem ratios of C: N: P hydrolyzing enzyme activity, as indicated by logarithmic ratios of $\ln (\mathrm{BG}): \ln (\mathrm{LAP}+\mathrm{NAG}): \ln (\mathrm{AP})$.

\begin{tabular}{lll}
\hline Land use type & Depth $(\mathrm{cm})$ & Ecoenzymatic C: N: P ratios \\
\hline $\mathrm{W}$ & $0-10$ & $1: 1.23: 1.41$ \\
& $10-30$ & $1: 1.48: 1.85$ \\
$\mathrm{~S}$ & $0-10$ & $1: 1.14: 1.34$ \\
& $10-30$ & $1: 1.52: 2.02$ \\
$\mathrm{C}$ & $0-10$ & $1: 1.06: 1.12$ \\
& $10-30$ & $1: 1.23: 1.33$ \\
$\mathrm{U}$ & $0-10$ & $1: 1.63: 1.89$ \\
& $10-30$ & $1: 2.20: 2.50$ \\
\hline
\end{tabular}

Note : W, woodland; S, shrubland; C, cropland; U, uncultivated land; ecoenzymatic C: N: P ratios $=$ Ln (BG): Ln (NAG+LAP): Ln (AP); See Table1 for abbreviations.

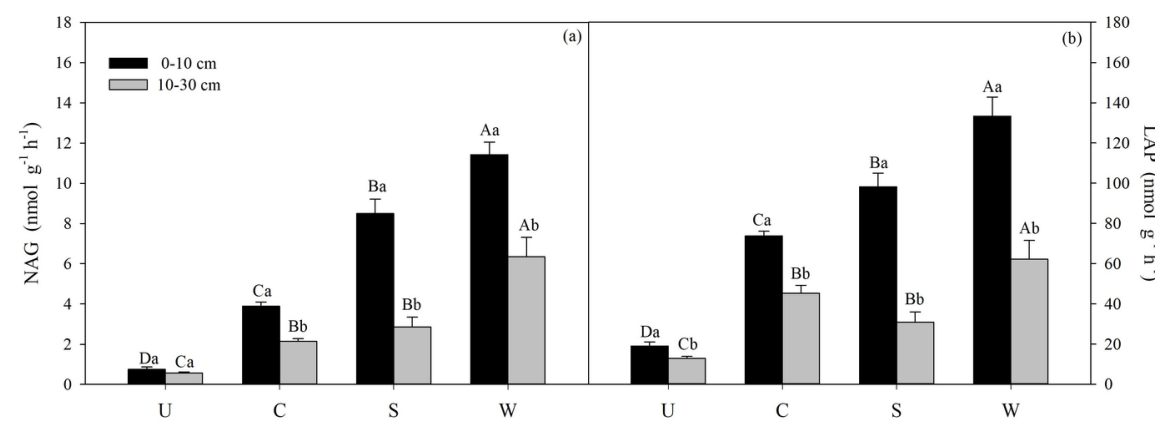



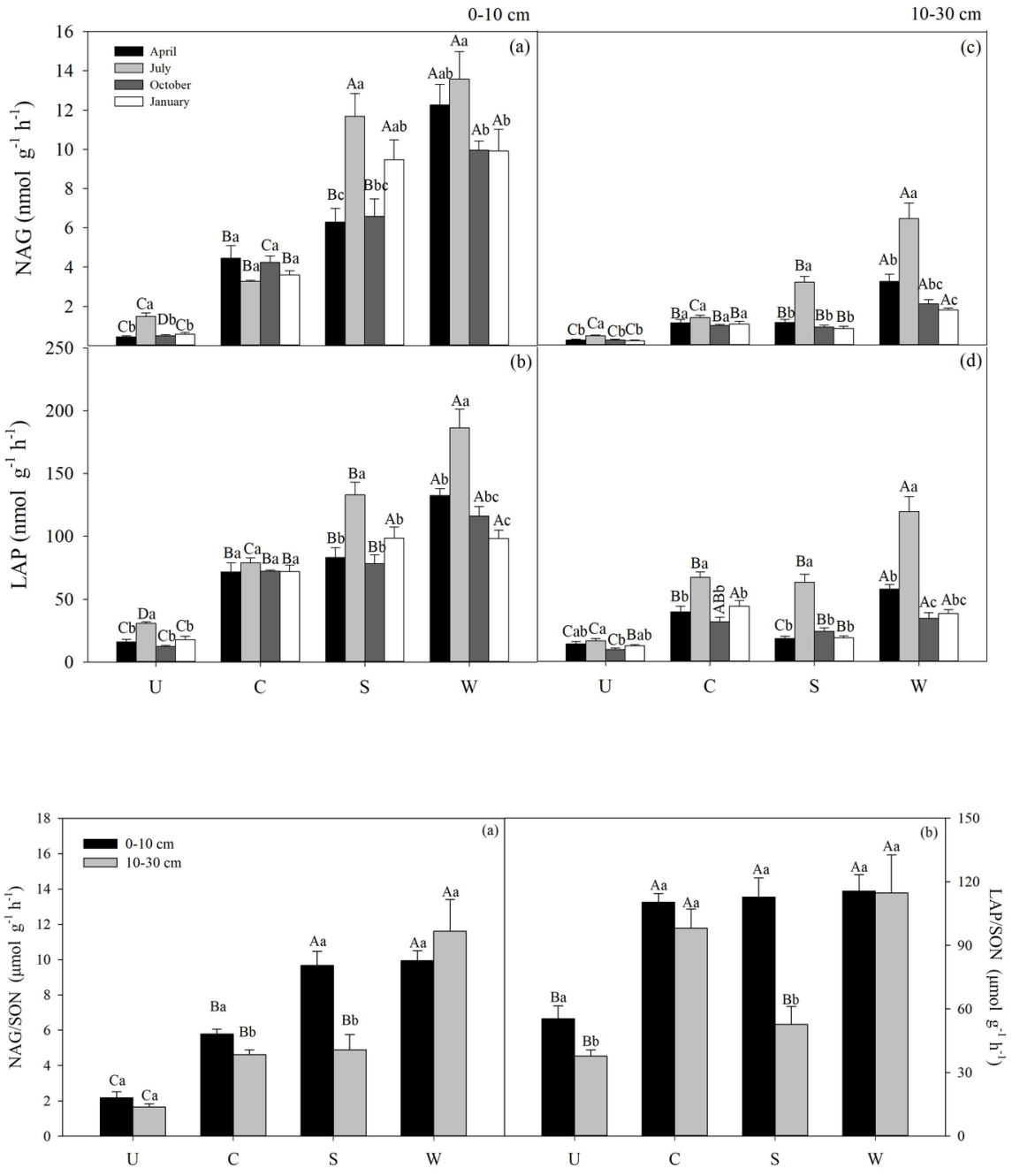

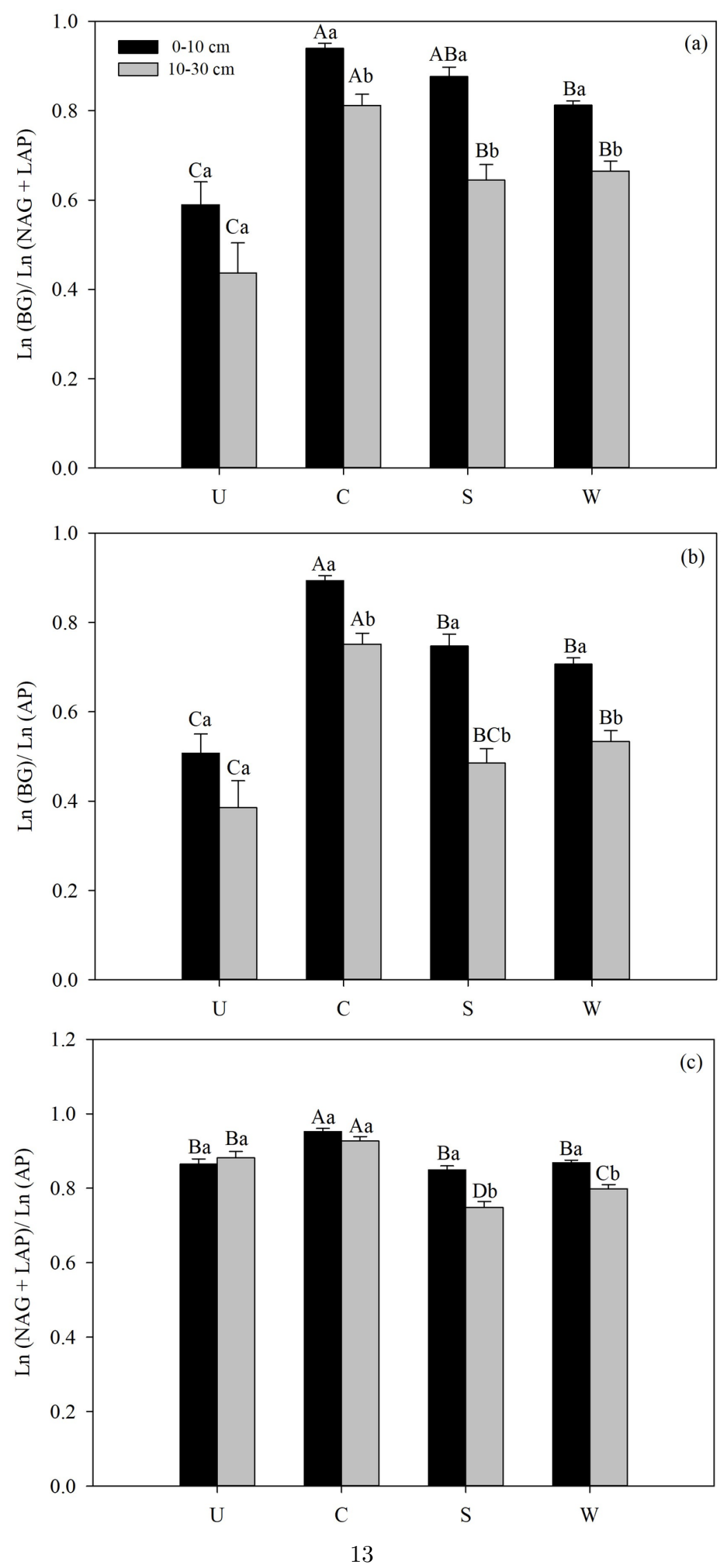

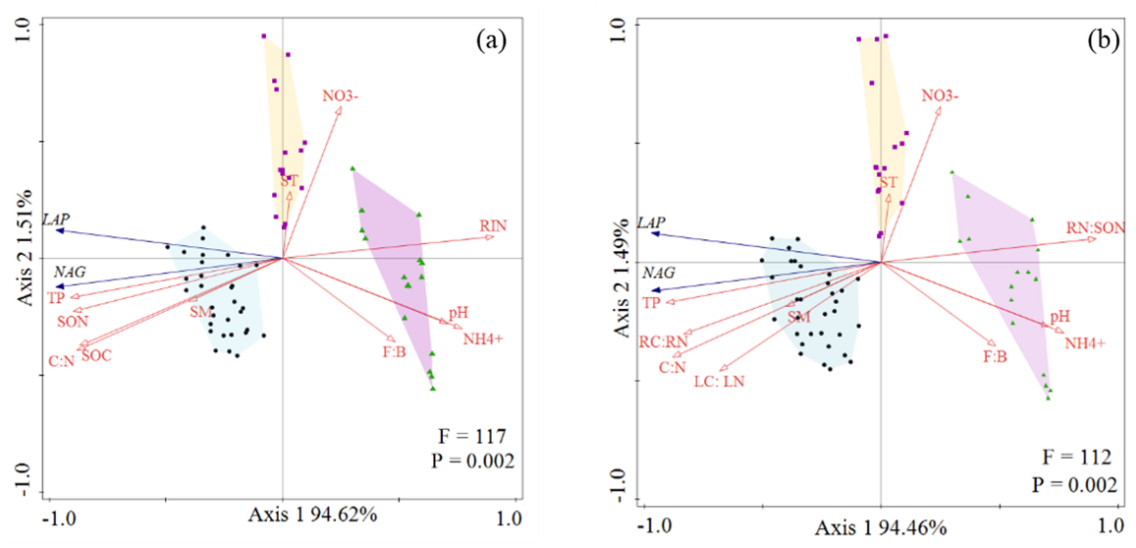